\title{
Effect of Glyphosate on Fusarium Head Blight in Wheat and Barley Under Different Soil Tillages
}

Marie-Eve Bérubé and Anne Vanasse, Département de phytologie, Université Laval, Québec, Québec, G1V 0A6, Canada; Sylvie Rioux, and Nicole Bourget, Centre de recherche sur les grains, Québec, Québec, G1P 3W8, Canada; and Yves Dion and Gilles Tremblay, Centre de recherche sur les grains, Saint-Mathieu-de-Beloeil, Québec, J3G 0E2, Canada

\begin{abstract}
Bérubé, M.-E., Vanasse, A., Rioux, S., Bourget, N., Dion, Y., and Tremblay, G. 2012. Effect of glyphosate on Fusarium head blight in wheat and barley under different soil tillages. Plant Dis. 96:338-344.

Fusarium head blight (FHB) is a serious disease in the wet conditions of eastern Canada. Tillage practices and herbicide applications have been reported to influence disease intensity. This study aimed to determine the effect of glyphosate on FHB development in wheat and barley and on Fusarium graminearum inoculum production under different soil tillages. The experiment was performed during 2 years (2007 and 2008) at two different sites in Quebec, Canada. Six trials were set in both sites, combining two cereal species (wheat and barley) and three soil tillages: moldboard plow, spring tillage (minimum-till), and direct drilling. For each trial, glyphosate or other herbicides were applied on

Roundup Ready soybean the year preceding cereal crops, constituting the main plots. The next year, three wheat and three barley cultivars were sown as subplots. FHB index, Fusarium-damaged kernels (FDK), deoxynivalenol (DON) content, and $F$. graminearum inoculum production were measured. Glyphosate had no significant effect on FHB index, FDK, or DON content, whatever the trial and the site. F. graminearum inoculum production was enhanced by glyphosate in only 1 of 12 trials. Cultivar effect was highly significant on DON content. The relationship between $F$. graminearum inoculum from soybean residues and DON content was weak.
\end{abstract}

Fusarium head blight (FHB) is a serious wheat and barley disease in eastern Canada (2). Fusarium graminearum Schwabe (Gibberella zeae (Schwein.) Petch) is the principal pathogen responsible for FHB (17), although other species may contribute to the disease development in cooler climates, such as F. avenaceum (Fr.) Sacc. (G. avenacea R.J. Cook), F. poae (Peck) Wollenw., and F. sporotrichioides Sherb. (4). FHB can result in significant reduced yield and seed quality (24). Moreover, this disease is associated with the production of deoxynivalenol (DON), a mycotoxin that makes the grain unfit for food or feed (28). F. graminearum produces spores on crop residues left on the soil surface, constituting the primary source of inoculum. These debris serve for the overwintering and the development of the fungus, which leads to spore production (33). F. graminearum is spread via windblown ascospores and macroconidia dispersed by splashing or wind-driven rain $(9,34)$. Ascospores may be dispersed long distances (23). The development of FHB is favored by frequent rainfalls, high humidity, and warm temperatures that coincide with wheat flowering or barley heading $(2,34)$. Therefore, this disease can be particularly devastating in areas characterized by wet weather, such as eastern Canada.

Tillage practices are suspected to affect the incidence and the severity of the disease, measured as DON accumulation in grain. Some studies revealed that the incidence and severity of FHB and DON content are lower when residues are buried by plowing, especially when the previous crop is a host species $(12,22,29,30)$ and when weather conditions are favorable for FHB development $(10,22)$. However, a lack of difference in FHB levels among minimum-till and no-till practices has been reported (12). Moreover, in some studies, FHB was not influenced by any tillage practice $(25,31)$. Other factors such as previous crops (31), weather conditions, susceptibility of cultivars, and previous occurrence of FHB

Corresponding author: A. Vanasse, E-mail: anne.vanasse@ fsaa.ulaval.ca

Accepted for publication 21 September 2011.

http://dx.doi.org/10.1094/PDIS-04-11-0297

(C) 2012 The American Phytopathological Society
(25) may be more prevalent and overpass the effect of the tillage practice.

Nevertheless, other crop production factors potentially influencing the inoculum production of Fusarium spp. began to get some attention, such as herbicides. Glyphosate (Roundup) is a highly effective, nonselective, and systemic herbicide used against a broad spectrum of weeds (15). Few studies attempted to evaluate the direct effects of glyphosate on FHB and, from the few that have been conducted, the results are often contradictory. One in vitro experiment demonstrated that glyphosate had not affected $F$. graminearum vegetative growth at concentrations equivalent to field rates of application (21). Other in vitro studies showed that most of the glyphosate formulations tested increased $F$. graminearum and $F$. avenaceum growth, while herbicide concentration rarely had a significant effect on it $(18,19)$. In a field experiment held in Norway, glyphosate did not have any significant effect on Fusarium spp. infection in harvested oat grain and did not interact with the tillage treatment (20). However, surveys conducted in eastern Saskatchewan revealed significant effects of glyphosate on FHB in wheat and barley under specific conditions. Wheat and barley fields where glyphosate had been previously applied under minimum-till were characterized by a higher FHB index caused by $F$. graminearum and $F$. avenaceum $(13,14)$.

Thus, it was necessary to further investigate the effects of glyphosate under different soil tillages on FHB in eastern Canada conditions where many growers use a Roundup Ready soybean cultivar the year preceding the cereal crop. The objective of this project was to determine the effect of glyphosate, used on soybean as the previous crop, on FHB intensity in wheat and barley and on $F$. graminearum inoculum production coming from the residues under different soil tillages.

\section{Materials and Methods}

Description of sites and treatments. The field experiments were established in the province of Quebec, Canada, during two growing seasons (2007 and 2008) at two different sites. The first one was located at the Agronomy Research Station of Laval University, Saint-Augustin-de-Desmaures $\left(46^{\circ} 45^{\prime} \mathrm{N}, 71^{\circ} 27^{\prime} \mathrm{W}\right)$, and the other one at the Centre de recherche sur les grains (CEROM), Saint-Mathieu-de-Beloeil $\left(45^{\circ} 34^{\prime} \mathrm{N}, 73^{\circ} 12^{\prime} \mathrm{W}\right)$. Six trials were set 
in both sites, combining two cereal species (wheat and barley) and three soil tillages: moldboard plow (MP), spring tillage (ST), and direct drilling (DD). At Saint-Augustin-de-Desmaures, three different loams of the Tilly series (Haplorthod) were used during this study. ST and DD trials were established in a soil with $49.2 \%$ sand, $38.2 \%$ silt, $12.6 \%$ clay, $4.1 \%$ organic matter, and pH 6.0 in 2007 and in a soil with $30.2 \%$ sand, $45.1 \%$ silt, $24.7 \%$ clay, $4.0 \%$ organic matter, and pH 6.2 in 2008, while MP trials were implanted in a soil with $39.8 \%$ sand, $44.1 \%$ silt, $16.1 \%$ clay, $3.5 \%$ organic matter, and pH 6.4 for both years. At Saint-Mathieu-de-Beloeil, two heavy clays of the Saint-Urbain series (Humaquept) were used during this study. All trials were established in a soil with $10.9 \%$ sand, $19.0 \%$ silt, $70.0 \%$ clay, $6.9 \%$ organic matter, and pH 6.1 in 2007 and in a soil with $5.2 \%$ sand, $23.0 \%$ silt, $71.9 \%$ clay, $3.5 \%$ organic matter, and pH 6.9 in 2008 . For each trial, a factorial experiment was implanted using a split-plot design with two herbicide treatments (glyphosate and no glyphosate) as main plots and three cultivar treatments (different susceptibility levels to FHB) as subplots. The six treatments (two herbicide treatments $\times$ three cultivar treatments) were replicated four times, resulting in 24 plots per trial and 144 plots per site.

One year before the implantation of the cereal field trials (2006 and 2007), glyphosate-resistant soybean ('Primo RR' for SaintAugustin-de-Desmaures and '2702RR' for Saint-Mathieu-de-Beloeil) was sown in whole moldboard-plowed fields at a row spacing of $36 \mathrm{~cm}$ in order to obtain 500,000 to 550,000 plants ha ${ }^{-1}$. The preceding crop was corn, except for the wheat-MP and barley-MP trials at Saint-Augustin-de-Desmaures in 2007, where the preceding crop was barley. Sowing dates at Saint-Augustin-de-Desmaures were 26 May 2006 and 25 May 2007 and those at Saint-Mathieude-Beloeil were 19 June 2006 and 12 June 2007. Prior to sowing, phosphorus and potassium were applied according to soil analysis and fertilizer recommendations (7) and incorporated using a field cultivator, whereas no nitrogen was applied because the crop was a pulse. Herbicide treatments for each year and site are described in Table 1. The other herbicides used in the "no glyphosate" treatment were chosen regarding the weed species to control in the field. Applications were made approximately 1 month after soybean sowing on wide strips in order to delimitate main plots of 6 by $6 \mathrm{~m}$ $\left(36 \mathrm{~m}^{2}\right)$ at Saint-Augustin-de-Desmaures and 9 by $6 \mathrm{~m}\left(54 \mathrm{~m}^{2}\right)$ at Saint-Mathieu-de-Beloeil. Harvesting dates of the main plots were 20 October 2006 and 16 and 17 October 2007 at Saint-Augustinde-Desmaures and 6 November 2006 and 8 November 2007 at Saint-Mathieu-de-Beloeil. All the crop residues were mowed and left on the plot surface.

Soil tillages were implanted after the soybean harvest. For both sites, MP consisted of a fall moldboard plowing with two passes of a field cultivator in the spring. ST consisted of one pass of a disk harrow with two passes of a field cultivator in the spring. DD had no tillage performed, except the use of a no-till drill for the sowing. The objective of these three different soil tillages was to produce different amounts of soybean residues on soil surfaces, which constitute the primary source of Fusarium inoculum the following season. Crop residue covers were measured at spring, after sowing, using a rope with 25 knots spaced out 6 in. apart. Knots touching a residue piece were counted and this number was multiplied by 4 in order to obtain crop residue covers in percentage (11). These results are given in Table 1.

In the years following the soybean crops (2007 and 2008), three wheat and three barley cultivars with distinct susceptibility levels to FHB were sown at 450 seeds $\mathrm{m}^{-2}$ for wheat and 375 seeds $\mathrm{m}^{-2}$ for barley, with a row spacing of $18 \mathrm{~cm}$, constituting the subplots. The dimensions were 2 by $6 \mathrm{~m}\left(12 \mathrm{~m}^{2}\right)$ at Saint-Augustin-deDesmaures and 3 by $6 \mathrm{~m}\left(18 \mathrm{~m}^{2}\right)$ at Saint-Mathieu-de-Beloeil. Wheat and barley of the MP and ST trials were planted using a conventional drill and, for the DD trials, a no-till drill. The wheat cultivars used were 'AC Barrie' (Agriculture and Agri-Food Canada, weakly susceptible), 'Orleans' (Semico Inc., moderately susceptible), and 'SS Fundy' (Minas Seed Coop Ltd., highly susceptible), while the barley cultivars used were 'Oceanik' (Semico Inc., moderately susceptible), 'Raquel' (Semico Inc., highly susceptible), and 'Perseis' (Coopérative fédérée du Québec, highly susceptible) (6). Sowing dates are given in Table 1. Nitrogen fertilization was of $70 \mathrm{~kg} \mathrm{ha-1}$ nonfractioned for the two cereals. Phosphorus and potassium were applied according to soil analysis and fertilizer recommendations (7). Annual broadleaved weeds were controlled with bromoxynil/MCPA (Buctril M, $280 \mathrm{~g}$ a.i ha ${ }^{-1}$ / $280 \mathrm{~g} \mathrm{a.i} \mathrm{ha}^{-1}$ ) applied at the three-leaf stage of the wheat and barley crops. Harvest dates for every year and site are shown in Table 1.

Disease measurements. In wheat trials, 3 weeks after the end of the flowering stage (Zadoks stage 69) (37), spikes were collected in two rows on a length of $0.5 \mathrm{~m}$ and put in a freezer. Infected spikelets were assessed visually on 30 spikes taken randomly from the samples collected in the field. FHB index (total number of infected spikelets/total number of spikelets $\times 100$ ) was calculated.

Six and seven rows of the middle of each plot were harvested at Saint-Augustin-de-Desmaures and Saint-Mathieu-de-Beloeil, respectively. From each wheat plot, a subsample of $15 \mathrm{~g}$ was prepared using a seed divider. The Fusarium-damaged kernels (FDK) was assessed visually on 300 kernels (number of infected kernels/total number of kernels $\times 100$ ). FHB index and FDK were not measured in barley trials because symptoms are not as distinctive as in wheat and may be confused with other diseases.

Table 1. Crop residue cover, herbicides applied, and cereal sowing and harvesting dates at Saint-Augustin-de-Desmaures and Saint-Mathieu-de-Beloeil in 2007 and $2008^{z}$

\begin{tabular}{|c|c|c|c|c|}
\hline \multirow[b]{2}{*}{ Variables } & \multicolumn{2}{|c|}{ Saint-Augustin-de-Desmaures } & \multicolumn{2}{|c|}{ Saint-Mathieu-de-Beloeil } \\
\hline & 2007 & 2008 & 2007 & 2008 \\
\hline \multicolumn{5}{|l|}{ Soybean } \\
\hline \multirow[t]{3}{*}{ Crop residue cover $(\%)$} & MP: 2.1 & MP: 2.3 & MP: 2.5 & MP: 0.7 \\
\hline & ST: 39.5 & ST: 35.8 & ST: 12.2 & ST: 14.2 \\
\hline & DD: 79.6 & DD: 81.5 & DD: 38.7 & DD: 30.6 \\
\hline \multicolumn{5}{|c|}{ Herbicides applied (g a.i. ha ${ }^{-1}$ ) } \\
\hline Glyphosate & Glyphosate (902) & Glyphosate (902) & Glyphosate (902) & Glyphosate (902) \\
\hline No glyphosate & Bentazon (840) & $\begin{array}{l}\text { Bentazon }(840, \text { ST; DD); } \\
\text { fomesafen }(240, \mathrm{MP})\end{array}$ & $\begin{array}{l}\text { Bentazon }(840)+ \\
\text { fenoxaprop-p-ethyl (54) }\end{array}$ & $\begin{array}{l}\text { Thifensulfuron methyl (8) } \\
+ \text { quizalofop p-ethyl (48) }\end{array}$ \\
\hline \multicolumn{5}{|l|}{ Cereals } \\
\hline \multicolumn{5}{|l|}{ Sowing date } \\
\hline MP & 7 May & 12 May & 23 May & 13 May \\
\hline ST & 8 May & 12 May & 23 May & 13 May \\
\hline $\mathrm{DD}$ & 8 May & 12 May & 25 May & 11 May \\
\hline \multicolumn{5}{|l|}{ Harvesting date } \\
\hline Wheat & 20 August & 25 August & 7 September & 20 August \\
\hline Barley & 16 August & 18 August & 29 August & 14 August \\
\hline
\end{tabular}

${ }^{\mathrm{z}}$ Abbreviations: $\mathrm{MP}=$ moldboard plow, $\mathrm{ST}=$ spring tillage, and DD = direct drilling. Herbicides: glyphosate $=$ Roundup WeatherMax, bentazon $=$ Basagran, fomesafen = Reflex, fenoxaprop-p-ethyl = Excel, thifensulfuron methyl $=$ Pinnacle, and quizalofop p-ethyl = Assure. 
For the DON content evaluation, another subsample of $300 \mathrm{~g}$ was prepared from every plot using a divider, including barley. The subsamples were ground and DON content was evaluated using an enzyme-linked immunosorbent assay (Veratox DON 5/5 and DON high sensitivity; Neogen Corporation).

$\boldsymbol{F}$. graminearum inoculum sampling. In the middle of each main plot (glyphosate and no glyphosate), two wooden stakes with metal supports were placed approximately $2 \mathrm{~m}$ apart. On each of them, one petri plate containing pentachloronitrobenzene (27) agar medium was placed. Petri plates faced the ground in order to capture Fusarium spp. spores as well as viable propagules emerging from the soybean residues during the critical period of infection of wheat and barley. The petri plate height was set at the ear base. This sampling method is based on the one described by Schmale et al. (32). Critical periods of infection were defined as 5 days before and after Zadoks stage 59 (heading completed) for barley and Zadoks stage 65 (50\% flowering completed) for wheat (37). Critical periods of wheat and barley happened almost simultaneously for each year and site. These periods corresponded to 1 to $11 \mathrm{July}$ 2007 and 4 to 14 July 2008 at Saint-Augustin-de-Desmaures and 10 to 20 July 2007 and 5 to 15 July 2008 at Saint-Mathieu-deBeloeil. Every morning, petri plates placed $24 \mathrm{~h}$ earlier in the field were replaced and put to incubation for 7 days, at room temperature (approximately 20 to $22^{\circ} \mathrm{C}$ ) in darkness. After the incubation time, "Fusarium-like" isolates were transferred to a rapid-identification medium agar (Fg medium; Quebact Laboratories Inc.). CFU characterized by a raspberry-red coloration were identified as $F$. graminearum. Identification was completed by microscopic observations based on the descriptions of Nelson et al. (26).

Statistical analysis. For each trial and site, combined data of 2007 and 2008 were subjected to an analysis of variance using PROC MIXED of SAS. Herbicide treatments, cultivars, and years were considered as fixed effects, while replicates within site were random effects. When an interaction between year and herbicide treatments or cultivars used occurred, statistical analysis was made for each year. In order to fulfill the assumptions of homogeneity of variance and normality of distribution, logarithmic $\left(\log _{\mathrm{e}} x\right)$ and square root $(\sqrt{ } x)$ transformations were executed on several trials data, which are indicated directly in tables. Significance was accepted or rejected using protected Fisher's least significant difference at $P \leq 0.05$. Depending on the trial, raw or detransformed data are shown. Regression coefficients of the relationship between $F$. graminearum inoculum and DON content in wheat and barley were calculated using replicates and cultivar treatments means of herbicide treatments $(n=2)$ coming from every soil tillage trial $(n$ $=3)$, site $(n=2)$, and year $(n=2)$. Consequently, for each species, 24 pairs of comparison were included in the calculation of the regression coefficients.

\section{Results}

Weather. The monthly temperatures and precipitations measured at the meteorological station located on each experimental site are presented for 2007 and 2008 growing seasons (Table 2). SaintAugustin-de-Desmaures was characterized by precipitation below normal at the beginning of the growing season, followed by high precipitation in June and July for both years. At Saint-Mathieu-deBeloeil, precipitation was almost always below normal, except for July 2008, where precipitation was above normal. Saint-Augustinde-Desmaures was the coolest site and temperatures were near normal in each year and site.

FHB index and FDK. Herbicide treatment had no significant effect on FHB index, whatever the site or the soil tillage trial (Table 3). However, FDK was affected by the herbicide treatment in the MP trial of Saint-Mathieu-de-Beloeil $(P=0.037)$. Plots that received glyphosate had $2.6 \%$ less FDK than plots that received other herbicides (Table 3). There was no interaction between the

Table 2. Monthly temperatures and precipitations for each site in 2007 and 2008 and average of the last 30 years in Quebec

\begin{tabular}{|c|c|c|c|c|c|c|}
\hline \multirow[b]{2}{*}{ Parameters } & \multicolumn{3}{|c|}{ Saint-Augustin-de-Desmaures } & \multicolumn{3}{|c|}{ Saint-Mathieu-de-Beloeil } \\
\hline & $2007^{w}$ & $2008^{w}$ & Average $e^{x}$ & $2007^{y}$ & $2008^{y}$ & Average $^{\mathrm{z}}$ \\
\hline \multicolumn{7}{|c|}{ Temperature $\left({ }^{\circ} \mathrm{C}\right)$} \\
\hline May & 12.0 & 10.6 & 11.4 & 14.1 & 12.3 & 13.4 \\
\hline June & 17.2 & 16.4 & 16.4 & 19.6 & 19.6 & 18.3 \\
\hline July & 18.7 & 19.4 & 19.5 & 19.9 & 21.2 & 20.4 \\
\hline August & 17.3 & 17.6 & 18.0 & 19.3 & 19.2 & 19.3 \\
\hline Mean & 16.3 & 16.0 & 16.3 & 18.2 & 18.1 & 17.9 \\
\hline \multicolumn{7}{|c|}{ Precipitation (mm) } \\
\hline May & 63 & 25 & 108 & 55 & 32 & 81 \\
\hline June & 77 & 201 & 112 & 63 & 68 & 92 \\
\hline July & 186 & 128 & 120 & 69 & 116 & 99 \\
\hline August & 130 & 105 & 111 & 87 & 101 & 93 \\
\hline Total & 457 & 459 & 451 & 273 & 317 & 365 \\
\hline
\end{tabular}

${ }^{w}$ Weather data from the meteorological station located on the Saint-Augustin-de-Desmaures site.

${ }^{x}$ Weather data from the Environment Canada meteorological station located at Saint-Augustin-de-Desmaures, Quebec.

${ }^{y}$ Weather data from the meteorological station located on the Saint-Mathieu-de-Beloeil site.

${ }^{\mathrm{z}}$ Weather data from the Environment Canada meteorological station located at Sainte-Madeleine, Quebec (located approximately $13 \mathrm{~km}$ away from SaintMathieu-de-Beloeil site).

Table 3. Fusarium head blight (FHB) index and Fusarium-damaged kernels (FDK) regarding the herbicide applied on the soybean previous crop for three soil tillages in wheat at Saint-Augustin-de-Desmaures and Saint-Mathieu-de-Beloeil (means of 2007 and 2008) ${ }^{\mathrm{x}}$

\begin{tabular}{|c|c|c|c|c|c|c|}
\hline \multirow[b]{2}{*}{ Trial } & \multicolumn{3}{|c|}{ Saint-Augustin-de-Desmaures } & \multicolumn{3}{|c|}{ Saint-Mathieu-de-Beloeil } \\
\hline & MP & ST & DD & MP & ST & DD \\
\hline \multicolumn{7}{|c|}{ FHB index $(\%)$} \\
\hline $\mathrm{G}$ & $3.1 \mathrm{a}$ & $6.4 \mathrm{a}^{\mathrm{y}}$ & $3.5 \mathrm{a}^{\mathrm{z}}$ & $12.1 \mathrm{a}$ & $8.3 \mathrm{a}$ & $6.7 \mathrm{a}^{\mathrm{z}}$ \\
\hline NG & $2.9 \mathrm{a}$ & $6.3 \mathrm{a}^{\mathrm{y}}$ & $3.6 \mathrm{a}^{\mathrm{z}}$ & $12.1 \mathrm{a}$ & $8.1 \mathrm{a}$ & $6.2 \mathrm{a}^{\mathrm{z}}$ \\
\hline \multicolumn{7}{|c|}{ FDK (\%) } \\
\hline $\mathrm{G}$ & $6.7 \mathrm{a}^{\mathrm{y}}$ & $8.5 \mathrm{a}$ & $7.3 \mathrm{a}$ & $15.0 \mathrm{~b}^{\mathrm{z}}$ & $16.6 \mathrm{a}$ & $10.1 \mathrm{a}^{\mathrm{z}}$ \\
\hline NG & $8.0 \mathrm{a}^{\mathrm{y}}$ & $8.2 \mathrm{a}$ & $8.7 \mathrm{a}$ & $17.6 \mathrm{a}^{\mathrm{z}}$ & $16.0 \mathrm{a}$ & $10.7 \mathrm{a}^{\mathrm{z}}$ \\
\hline
\end{tabular}

${ }^{x}$ Abbreviations: $\mathrm{MP}=$ moldboard plow, $\mathrm{ST}=$ spring tillage, $\mathrm{DD}=$ direct drilling, $\mathrm{G}=$ glyphosate, and $\mathrm{NG}=$ no glyphosate. For each variable, means followed by the same letter are not significantly different at $P \leq 0.05$ within each column.

$\mathrm{y} \sqrt{ } x$ Detransformed means.

${ }^{\mathrm{z}} \ln x$ Detransformed means. 
herbicide treatment and the sampling year for both variables. Although sites were not compared statistically, FHB index and FDK results at Saint-Augustin-de-Desmaures were numerically lower than those at Saint-Mathieu-de-Beloeil (Table 3).

DON content and $F$. graminearum inoculum production. Whatever the site or the soil tillage trial, glyphosate application did not result in higher DON content compared with the other herbicides applied (Table 4). No interaction between the herbicide treatment and the sampling year was observed for DON content. Nevertheless, a significant interaction occurred between the herbicide treatment and the cultivar used in the barley-DD trial at SaintAugustin-de-Desmaures $(P=0.023)$ (Table 5). Within this trial, DON content of the highly susceptible Raquel was significantly higher when glyphosate was applied compared with the other herbicides. However, the other highly susceptible cultivar, Perseis, and the moderately susceptible Oceanik were not affected by the herbicide treatments (Table 5).

Because an interaction between the cultivar used and the sampling year happened in almost all trials, statistical analysis of the cultivar effect was made for each year. Except for two trials (wheat-DD 2007 and barley-DD 2008 at Saint-Augustin-deDesmaures), cultivar effect was highly significant. Generally, AC Barrie was the least-affected wheat cultivar and SS Fundy was the most-affected one. In the barley trials, Oceanik was the leastsusceptible cultivar whereas Perseis was the most-susceptible one (Table 6). The highest DON contents were obtained in wheat at Saint-Mathieu-de-Beloeil and the lowest in barley at SaintAugustin-de-Desmaures. Overall, Saint-Augustin-de-Desmaures results were numerically lower than those of Saint-Mathieu-deBeloeil (Tables 4 and 6).

Looking at $F$. graminearum inoculum production, herbicide treatment had a significant effect in wheat-ST $(P=0.035)$ and barley-DD $(P=0.036)$ trials at Saint-Mathieu-de-Beloeil and did not interact with the sampling year (Table 7). In the wheat-ST trial, the daily mean number of $F$. graminearum $C F U$ was higher when other herbicides were applied, whereas glyphosate application was responsible for higher inoculum production in the barley-DD trial (Table 7). Interactions between herbicide treatments and sampling years were detected regarding this variable in wheat-MP and wheat-DD trials at Saint-Augustin-de-Desmaures (Table 8). In the wheat-MP trial, herbicide effect was not significant in 2007. However, in 2008, other herbicide applications caused a significantly higher $F$. graminearum inoculum production $(P=0.045)$. Despite the presence of an interaction between years in the wheat-DD trial, there was no significant effect of the herbicide treatments in 2007 and 2008. Still, other herbicide applications tended to give a higher result in 2008 compared with glyphosate application $(P=0.083)$ (Table 8).

Relationship between $\boldsymbol{F}$. graminearum inoculum and DON content. The relationship between $F$. graminearum inoculum coming from crop residues and DON content in wheat and barley grain was calculated (Fig. 1). Both regression coefficients were signifi- cant, although $P$ value for wheat was more significant (wheat: $P=$ 0.004; barley: $P=0.014$ ). However, these relationships were rather weak for both cereal species (wheat: $R^{2}=0.321$; barley: $R^{2}=$ 0.247). The smallest DON content values represented in each graph (less than $0.5 \mathrm{ppm}$ ) seemed to distort the interpretation of the relationship (Fig. 1). In fact, when these results were removed from the regression analysis, both relationships were no longer significant, with extremely low regression coefficients (wheat: $P=0.667$, $R^{2}=0.011$; barley: $P=0.297, R^{2}=0.068$ ). No strong relationships occurred when statistical analyses were made separating years and sites.

\section{Discussion}

The herbicide treatments had no impact on FHB index and DON content of wheat, whatever the soil tillage and the site. There was a significant effect on FDK at Saint-Mathieu-de-Beloeil but the higher FDK value was for the no glyphosate treatment and not the glyphosate one. DON content of barley was not influenced significantly by herbicide treatments. However, there was a herbicidecultivar interaction in the DD trial at Saint-Augustin-de-Desmaures showing a higher DON content in Raquel when glyphosate was used. Even if the DON content was significantly higher, there was no significant difference between the herbicide treatments regarding the $F$. graminearum inoculum production coming from the crop residues of the barley-DD trial at Saint-Augustin-de-Desmaures. Fernandez et al. (14) reported that glyphosate had a greater effect on intermediately-resistant barley genotypes. However, in our study, the intermediately-resistant Oceanik was not affected significantly by the herbicide treatments. Therefore, it seems to be an artifact more than a barley genotype-specific interaction.

Regarding $F$. graminearum inoculum production, 2 of 12 trials were affected significantly by the herbicide treatments (barley-DD and wheat-ST at Saint-Mathieu-de-Beloeil), with glyphosate leading to more CFU only in the barley-DD trial. In one trial showing a herbicide-year interaction effect (wheat-MP trial at SaintAugustin-de-Desmaures), there was also a significant effect of herbicide treatments on $F$. graminearum inoculum production in a 2008 trial. However, once again, this was due to a higher daily mean number of $F$. graminearum $\mathrm{CFU}$ collected from the no glyphosate plots.

Table 5. Deoxynivalenol (DON) content regarding the interaction between the herbicide applied and the cultivar used in barley-direct drilling (DD) trial at Saint-Augustin-de-Desmaures (means of 2007 and 2008) ${ }^{\mathrm{z}}$

\begin{tabular}{lccc}
\hline & \multicolumn{3}{c}{ DON content (ppm) } \\
\cline { 2 - 4 } Barley/DD & Oceanik & Raquel & Perseis \\
\hline Glyphosate & $0.36 \mathrm{~b}$ & $0.65 \mathrm{a}$ & $0.46 \mathrm{ab}$ \\
No glyphosate & $0.48 \mathrm{ab}$ & $0.36 \mathrm{~b}$ & $0.53 \mathrm{ab}$ \\
\hline
\end{tabular}

${ }^{\mathrm{z}}$ All data are $\ln x$ detransformed means. Means followed by the same letter are not significantly different at $P \leq 0.05$.

Table 4. Deoxynivalenol (DON) content regarding the herbicide applied on the soybean previous crop for three soil tillages in wheat and barley at SaintAugustin-de-Desmaures and Saint-Mathieu-de Beloeil (means of 2007 and 2008) ${ }^{\mathrm{y}}$

\begin{tabular}{|c|c|c|c|c|c|c|}
\hline \multirow[b]{3}{*}{ Trial } & \multicolumn{6}{|c|}{ DON content (ppm) } \\
\hline & \multicolumn{3}{|c|}{ Saint-Augustin-de-Desmaures } & \multicolumn{3}{|c|}{ Saint-Mathieu-de-Beloeil } \\
\hline & MP & ST & DD & MP & ST & DD \\
\hline \multicolumn{7}{|l|}{ Wheat } \\
\hline G & $2.2 \mathrm{a}$ & $1.5 \mathrm{a}^{\mathrm{z}}$ & $2.4 \mathrm{a}$ & $9.0 \mathrm{a}$ & $8.3 \mathrm{a}$ & $6.2 \mathrm{a}$ \\
\hline NG & $2.4 \mathrm{a}$ & $1.6 \mathrm{a}^{\mathrm{z}}$ & $2.6 \mathrm{a}$ & $9.1 \mathrm{a}$ & $8.1 \mathrm{a}$ & $6.5 \mathrm{a}$ \\
\hline \multicolumn{7}{|c|}{ Barley } \\
\hline G & $0.8 \mathrm{a}$ & $0.9 \mathrm{a}$ & Int. & $5.2 \mathrm{a}^{\mathrm{z}}$ & $4.1 \mathrm{a}$ & $3.2 \mathrm{a}$ \\
\hline NG & $1.0 \mathrm{a}$ & $0.6 \mathrm{a}$ & Int. & $5.2 \mathrm{a}^{\mathrm{z}}$ & $5.4 \mathrm{a}$ & $3.3 \mathrm{a}$ \\
\hline
\end{tabular}

y Abbreviations: $\mathrm{MP}=$ moldboard plow, $\mathrm{ST}=$ spring tillage, $\mathrm{DD}=$ direct drilling, $\mathrm{G}=$ glyphosate, $\mathrm{NG}=$ no glyphosate, and Int. $=$ interaction between herbicide treatment and cultivar treatment. For each cereal, means followed by the same letter are not significantly different at $P \leq 0.05$ within each column.

$\mathrm{z} \sqrt{ } x$ Detransformed means. 
These results are in concordance with those of Henriksen and Elen (20), who found that a fall application of glyphosate was not responsible for a higher proportion of Fusarium spp.-infected grain the next year in Norway. However, our conclusions are against those of Fernandez et al. $(13,14)$, who said that glyphosate application within 18 months before wheat or barley crops and under minimum-till was responsible for more FHB in Saskatchewan.

The lack of glyphosate effect on FHB in our experiments may be explained by the absence of glyphosate on soybean residues, in the hypothesis that glyphosate can also enhance $F$. graminearum sporulation as it can for its vegetative growth $(18,19)$. It has been proven that straw of cereals that received glyphosate in preharvest could contain herbicide residues levels up to $60 \mathrm{ppm}$ (16). However, a study in Argentina showed that Roundup Ready soybean plants treated with glyphosate contained less than $6 \mathrm{ppm}$ of glyphosate and its metabolites at harvest, several months after treatment, with the highest quantities obtained after two applications of the herbicide (1). Because only one glyphosate application was done in our experiment, we can suppose that glyphosate concentration was very low in crop residues. Unfortunately, we are not able to confirm this hypothesis because the glyphosate residue level was not quantified in any of the crop residues prior to planting the cereal crops. Precipitation could also cause leaching of the herbicide out of the desiccated residues left on the ground after harvest (8). This phenomenon may have happened in our experiment. Soybean residues were mowed after harvest in order to simulate the use of a commercial combine, and this operation may have greatly exposed glyphosate contained in the residues to leaching by rain and snow. Total precipitation received per year was 1,000 mm in the Saint-Mathieu-de-Beloeil area and 1,231 mm in the SaintAugustin-de-Desmaures area. This was at least two times more precipitation than the $451 \mathrm{~mm}$ received in Yorkton, Saskatchewan, the area where Fernandez's surveys were conducted (5). Therefore, it is likely that glyphosate was not present any more on soybean residues in the next growing season. This could partially explain why the herbicide did not have any effect on the production of $F$. graminearum inoculum in our experiments and, consequently, on FHB development.

Moreover, the weak relationships calculated between $F$. graminearum inoculum production from crop residues and DON con-

Table 8. Daily mean number of Fusarium graminearum CFU coming from crop residues during the critical period of infection regarding the interaction between the herbicide applied and the sampling year in wheatmoldboard plow and wheat-direct drilling trials at Saint-Augustin-deDesmaures $^{\mathrm{y}}$

\begin{tabular}{lccccc}
\hline & \multicolumn{4}{c}{ CFU day $^{-1}$} \\
\cline { 2 - 3 } \cline { 5 - 6 } Trial & \multicolumn{2}{c}{ Moldboard plow } & & \multicolumn{2}{c}{ Direct drilling } \\
\cline { 2 - 3 } \cline { 5 - 6 } & $\mathbf{2 0 0 7}$ & $\mathbf{2 0 0 8}$ & & $\mathbf{2 0 0 7}$ & $\mathbf{2 0 0 8}$ \\
\hline Glyphosate & $0.23 \mathrm{a}^{\mathrm{z}}$ & $1.69 \mathrm{~b}$ & & $0.15 \mathrm{a}$ & $0.77 \mathrm{a}$ \\
No glyphosate & $0.21 \mathrm{a}^{\mathrm{z}}$ & $2.22 \mathrm{a}$ & & $0.14 \mathrm{a}$ & $1.84 \mathrm{a}$ \\
\hline
\end{tabular}

${ }^{y}$ Means followed by the same letter are not significantly different at $P \leq$ 0.05 within each column.

${ }^{\mathrm{z}} \ln x$ Detransformed means.

Table 6. Deoxynivalenol (DON) content regarding the cultivar used for three soil tillages in wheat and barley at Saint-Augustin-de-Desmaures and SaintMathieu-de-Beloeil in 2007 and $2008^{y}$

\begin{tabular}{|c|c|c|c|c|c|c|}
\hline \multirow[b]{3}{*}{ Year, cultivar } & \multicolumn{6}{|c|}{ DON content (ppm) } \\
\hline & \multicolumn{3}{|c|}{ Saint-Augustin-de-Desmaures } & \multicolumn{3}{|c|}{ Saint-Mathieu-de-Beloeil } \\
\hline & MP & ST & DD & MP & ST & DD \\
\hline \multicolumn{7}{|l|}{ Wheat 2007} \\
\hline AC Barrie & $0.11 \mathrm{~b}^{\mathrm{z}}$ & $0.18 \mathrm{c}^{\mathrm{z}}$ & $0.06 \mathrm{a}^{\mathrm{z}}$ & $7.7 \mathrm{~b}$ & $6.3 \mathrm{~b}$ & $3.0 \mathrm{c}$ \\
\hline Orleans & $0.14 b^{\mathrm{z}}$ & $0.25 \mathrm{~b}^{\mathrm{z}}$ & $0.06 \mathrm{a}^{\mathrm{z}}$ & $8.4 \mathrm{~b}$ & $7.0 \mathrm{~b}$ & $3.7 \mathrm{~b}$ \\
\hline SS Fundy & $0.58 \mathrm{a}^{\mathrm{z}}$ & $0.71 \mathrm{a}^{\mathrm{z}}$ & $0.12 \mathrm{a}^{\mathrm{z}}$ & $13.4 \mathrm{a}$ & $10.8 \mathrm{a}$ & $7.9 \mathrm{a}$ \\
\hline \multicolumn{7}{|l|}{ Wheat 2008} \\
\hline AC Barrie & $2.8 \mathrm{c}$ & $2.9 \mathrm{~b}$ & $3.3 \mathrm{~b}$ & $5.2 \mathrm{~b}$ & $5.5 \mathrm{~b}$ & $5.2 \mathrm{~b}^{\mathrm{z}}$ \\
\hline Orleans & $5.4 \mathrm{a}$ & $5.0 \mathrm{a}$ & $4.3 \mathrm{~b}$ & $5.5 \mathrm{~b}$ & $6.6 \mathrm{~b}$ & $5.6 \mathrm{~b}^{\mathrm{z}}$ \\
\hline SS Fundy & $4.6 \mathrm{~b}$ & $3.2 \mathrm{~b}$ & $7.1 \mathrm{a}$ & $13.6 \mathrm{a}$ & $12.9 \mathrm{a}$ & $12.6 \mathrm{a}^{\mathrm{z}}$ \\
\hline \multicolumn{7}{|l|}{ Barley 2007} \\
\hline Oceanik & $0.13 b^{z}$ & $0.13 \mathrm{~b}$ & $0.13 \mathrm{~b}$ & $7.5 \mathrm{~b}$ & $3.6 \mathrm{c}$ & $1.6 \mathrm{c}$ \\
\hline Raquel & $0.23 \mathrm{a}^{\mathrm{z}}$ & $0.20 \mathrm{a}$ & $0.20 \mathrm{a}$ & $10.5 \mathrm{a}$ & $6.6 \mathrm{~b}$ & $4.6 \mathrm{~b}$ \\
\hline Perseis & $0.25 \mathrm{a}^{\mathrm{z}}$ & $0.22 \mathrm{a}$ & $0.21 \mathrm{a}$ & $11.9 \mathrm{a}$ & $8.7 \mathrm{a}$ & $5.5 \mathrm{a}$ \\
\hline \multicolumn{7}{|l|}{ Barley 2008} \\
\hline Oceanik & $0.9 \mathrm{c}^{\mathrm{z}}$ & $0.8 \mathrm{~b}$ & $1.3 \mathrm{a}^{\mathrm{z}}$ & $1.6 \mathrm{c}$ & $2.3 \mathrm{c}$ & $1.6 \mathrm{c}$ \\
\hline Raquel & $1.4 \mathrm{~b}^{\mathrm{z}}$ & $1.0 \mathrm{~b}$ & $1.2 \mathrm{a}^{\mathrm{z}}$ & $2.2 \mathrm{~b}$ & $3.4 \mathrm{~b}$ & $3.0 \mathrm{~b}$ \\
\hline Perseis & $2.3 \mathrm{a}^{\mathrm{z}}$ & $2.1 \mathrm{a}$ & $1.2 \mathrm{a}^{\mathrm{z}}$ & $2.6 \mathrm{a}$ & $4.0 \mathrm{a}$ & $3.4 \mathrm{a}$ \\
\hline
\end{tabular}

y Abbreviations: $\mathrm{MP}=$ moldboard plow, $\mathrm{ST}=$ spring tillage, and DD = direct drilling. For each cereal-year combination, means followed by the same letter are not significantly different at $P \leq 0.05$ within each column.

${ }^{\mathrm{z}} \ln x$ Detransformed means.

Table 7. Daily mean number of Fusarium graminearum CFU coming from crop residues during the critical period of infection regarding herbicide effect for three soil tillages in wheat and barley at Saint-Augustin-de-Desmaures and Saint-Mathieu-de-Beloeil (means of 2007 and 2008) ${ }^{y}$

\begin{tabular}{|c|c|c|c|c|c|c|}
\hline \multirow[b]{3}{*}{ Trial } & \multicolumn{6}{|c|}{ CFU day ${ }^{-1}$} \\
\hline & \multicolumn{3}{|c|}{ Saint-Augustin-de-Desmaures } & \multicolumn{3}{|c|}{ Saint-Mathieu-de-Beloeil } \\
\hline & MP & ST & DD & MP & ST & DD \\
\hline \multicolumn{7}{|l|}{ Wheat } \\
\hline $\mathrm{G}$ & Int. & $0.53 \mathrm{a}$ & Int. & $1.63 \mathrm{a}$ & $1.08 \mathrm{~b}$ & $1.11 \mathrm{a}$ \\
\hline NG & Int. & $0.43 \mathrm{a}$ & Int. & $1.61 \mathrm{a}$ & $1.44 \mathrm{a}$ & $0.97 \mathrm{a}$ \\
\hline \multicolumn{7}{|c|}{ Barley } \\
\hline G & $0.70 \mathrm{a}^{\mathrm{z}}$ & $0.44 \mathrm{a}^{\mathrm{z}}$ & $0.37 \mathrm{a}$ & $1.22 \mathrm{a}$ & $0.57 \mathrm{a}$ & $0.85 \mathrm{a}$ \\
\hline NG & $0.96 \mathrm{a}^{\mathrm{z}}$ & $0.44 \mathrm{a}^{\mathrm{z}}$ & $0.26 \mathrm{a}$ & $1.00 \mathrm{a}$ & $0.91 \mathrm{a}$ & $0.68 \mathrm{~b}$ \\
\hline
\end{tabular}

${ }^{y}$ Abbreviations: $\mathrm{MP}=$ moldboard plow, $\mathrm{ST}=$ spring tillage, $\mathrm{DD}=$ direct drilling, $\mathrm{G}=$ glyphosate, $\mathrm{NG}=$ no glyphosate, and Int. $=$ interaction between herbicide treatment and year. For each cereal, means followed by the same letter are not significantly different at $P \leq 0.05$ within each column.

$\mathrm{z} \sqrt{ } x$ Detransformed means. 
tent in wheat and barley grain demonstrated that $F$. graminearum inoculum coming from soybean residues was not the only factor involved in FHB development. Thus, even if glyphosate would have enhanced $F$. graminearum vegetative growth $(18,19)$ and further inoculum production, the other factors involved in FHB development may have hidden the glyphosate effect.

The lack of response of FHB to tillage practices was also reported many times in the literature $(25,31,35)$. It has been shown that the susceptibility of the previous crop to FHB played a more important role in the development of the disease. In our study, Roundup Ready soybean had been sown the year before wheat and barley crops because this is a practice commonly used by growers. Even if soybean can support growth of $F$. graminearum (3), host crop residues are still more colonized $(12,25)$. In addition, it has been reported that tillage practices had no effect on FHB if the precedent crop was soybean compared with corn or wheat $(12,35)$.

Other well-known factors had a greater influence on FHB in this study. Cultivar susceptibility was highly associated with DON production in wheat and barley grain. These results followed the FHB resistance levels known for each cultivar (6). This was proven many other times $(13,22,31)$. Finally, the importance of climatic conditions during the critical period of infection could not be avoided. Disease measurements were numerically higher at SaintMathieu-de-Beloeil compared with Saint-Augustin-de-Desmaures, which can be explained by higher temperatures prevailing there during the critical period, combined with humid conditions. This effect is well reported in the literature $(34,36)$.

In conclusion, it seems that glyphosate has no real impact on development of FHB and on $F$. graminearum inoculum production coming from soybean residues under eastern Canada humid conditions, whatever the site, the cereal species, or the crop residue

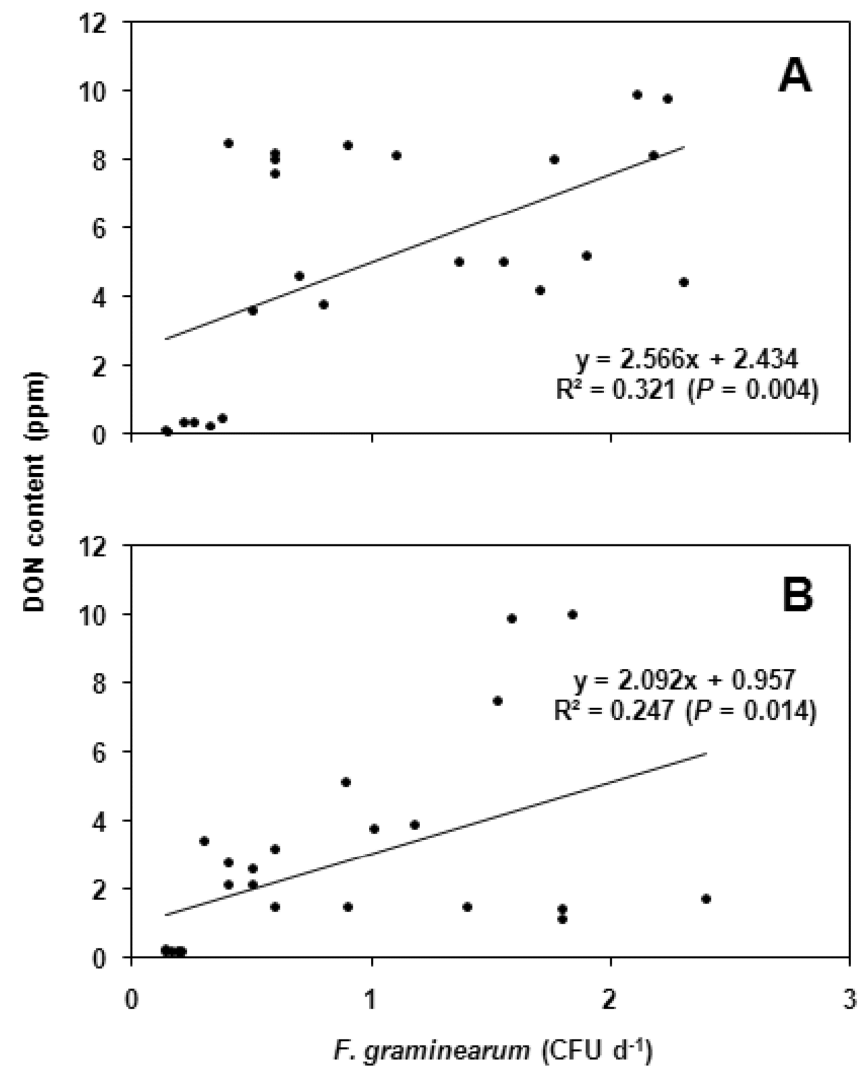

Fig. 1. Relationship between the daily mean number of Fusarium graminearum CFU coming from crop residues during the critical period of infection and deoxynivalenol (DON) content. A, Wheat and B, barley grains. For each species, 24 pairs of comparison are included in the regression: two pairs of comparison (glyphosate cultivar mean and no glyphosate cultivar mean) of every soil tillage trial $(n=3)$, site $(n=2)$, and year $(n=2)$. cover. Cultivar susceptibility and climatic conditions appear to have a greater effect on FHB intensity.

\section{Acknowledgments}

This work was supported by the ministère de l'Agriculture, des Pêcheries et de l'Alimentation du Québec and by the Natural Sciences and Engineering Research Council of Canada. We thank M. Tremblay, F. Gagnon, D. Marois, M. Lacroix, and M. Bussières for technical assistance; A. Brégard for helping in the statistical analysis; and all the persons who helped out with the Fusarium data.

\section{Literature Cited}

1. Arregui, M. C., Lenardón, A., Sanchez, D., Maitre, M. I., Scotta, R., and Enrique, S. 2003. Monitoring glyphosate residues in transgenic glyphosateresistant soybean. Pest Manage. Sci. 60:163-166.

2. Bailey, K. L., Couture, L., Gossen, B. D., Gugel, R. K., and Morrall, R. A. A. 2004. Maladies des grandes cultures au Canada. Société canadienne de phytopathologie.

3. Baird, R. E., Mullinix, B. G., Peery, A. B., and Lang, M. L. 1997. Diversity and longevity of the soybean debris mycobiota in a no-tillage system. Plant Dis. 81:530-534.

4. Bourdages, J. V., Marchand, S., Rioux, S., and Belzile, F. J. 2006. Diversity and prevalence of Fusarium species from Quebec barley fields. Can. J. Plant Pathol. 28:419-425.

5. Canada's National Climate Archive. 2008. Canadian Climate Normals or Averages 1971-2000. Environment Canada. Online publication. http:// climate.weatheroffice.gc.ca/climate_normals/index_e.html.

6. Centre de recherche sur les grains (CEROM). 2007. Résultats des essais de maïs-grain et de cultivars de plantes oléoprotéagineuses 2006 et recommandations de cultivars de céréales 2007. Saint-Bruno-deMontarville, QC

7. Centre de référence en agriculture et agroalimentaire du Québec (CRAAQ). 2003. Guide de référence en fertilisation. Sainte-Foy, QC.

8. Cessna, A. J., and Waddington, J. 1995. Dissipation of glyphosate and its metabolite AMPA in established crested wheatgrass following spring application. Can. J. Plant Sci. 75:759-762.

9. Champeil, A., Doré, T., and Fourbet, J. F. 2004. Fusarium head blight: epidemiological origin of the effects of cultural practices on head blight attacks and the production of mycotoxins by Fusarium in wheat grains. Plant Sci. 166:1389-1415.

10. Champeil, A., Fourbet, J. F., Doré, T., and Rossignol, L. 2004. Influence of cropping system on Fusarium head blight and mycotoxin levels in winter wheat. Crop Prot. 23:531-537.

11. Conseil des productions végétales du Québec Inc. (CPVQ). 2000. Impacts sur la couverture de résidus. Guide des pratiques de conservation en grandes cultures, Feuillet 2-E.

12. Dill-Macky, R., and Jones, R. K. 2000. The effect of previous crop residues and tillage on Fusarium head blight of wheat. Plant Dis. 84:71-76.

13. Fernandez, M. R., Selles, F., Gehl, D., DePauw, R. M., and Zentner, R. P. 2005. Crop production factors associated with Fusarium head blight in spring wheat in eastern Saskatchewan. Crop Sci. 45:1908-1916.

14. Fernandez, M. R., Zentner, R. P., DePauw, R. M., Gehl, D., and Stevenson, F. C. 2007. Impacts of crop production factors on Fusarium head blight in barley in eastern Saskatchewan. Crop Sci. 47:1574-1584.

15. Franz, J.E. 1985. Discovery, development and chemistry of glyphosate. Pages 3-17 in: The Herbicide Glyphosate. E. Grossbard and D. Atkinson, eds. Butterworths, London.

16. Gilbert, G., Bernier, D., and Lacroix, C. 2006. Un vieux problème chez le fraisier enfin solutionné. Laboratoire de diagnostic en phytoprotection, MAPAQ. Online publication. http://www.agrireseau.qc.ca/references/13/ Un\%20vieux \%20probl\%c3\%a8me\%20de\%20fraisier.pdf.

17. Gilbert, J., and Tekauz, A. 2000. Review: recent developments in research on Fusarium head blight of wheat in Canada. Can. J. Plant Pathol. 22:1-8.

18. Hanson, K. G., and Fernandez, M. R. 2002. In vitro growth of Fusarium head blight fungi as affected by glyphosate-based herbicides. (Abstr.) Can. J. Plant Pathol. 24:387.

19. Hanson, K. G., and Fernandez, M. R. 2003. Glyphosate herbicides affect plant pathogenic fungi. (Abstr.) Can. J. Plant Pathol. 25:120.

20. Henriksen, B., and Elen, O. 2005. Natural Fusarium grain infection level in wheat, barley and oat after early application of fungicides and herbicides. J. Phytopathol. 153:214-220.

21. Jeffery, S., and Burgess, L. W. 1990. Growth of Fusarium graminearum Schwabe group 1 on media amended with atrazine, chlorsulfuron or glyphosate in relation to temperature and osmotic potential. Soil Biol. Biochem. 22:665-670.

22. Koch, H. J., Pringas, C., and Maerlaender, B. 2006. Evaluation of environmental and management effects on Fusarium head blight infection and deoxynivalenol concentration in the grain of winter wheat. Eur. J. Agron. 24:357-366.

23. Maldonado-Ramirez, S. L., Schmale, D. G., III, Shields, E. J., and Bergstrom, G. C. 2005. The relative abundance of viable spores of Gibberella zeae in the planetary boundary layer suggests the role of long-distance transport in regional epidemics of Fusarium head blight. Agric. For. Meteorol. 132:20-27. 
24. McMullen, M., Jones, R., and Gallenberg, D. 1997. Scab of wheat and barley: A re-emerging disease of devastating impact. Plant Dis. 81:13401348.

25. Miller, J. D., Culley, J., Fraser, K., Hubbard, S., Meloche, F., Ouellet, T., Seaman, W. L., Seifert, K. A., Turkington, K., and Voldeng, H. 1998. Effect of tillage practice on Fusarium head blight of wheat. Can. J. Plant Pathol. 20:95-103.

26. Nelson, P. E., Toussoun, T. A., and Marasas, W. F. O. 1983. Fusarium Species: An Illustrated Manual for Identification. Pennsylvania State University Press, University Park.

27. Papavizas, G. C. 1967. Evaluation of various media and antimicrobial agents for isolation of Fusarium from soil. Phytopathology 57: 848-852.

28. Prelusky, D. B., Rotter, B. A., and Rotter, R. G. 1994. Toxicology of mycotoxins. Pages 359-404 in: Mycotoxins in Grain: Compounds Other than Aflatoxin. J. D. Miller and H. L. Trenholm, eds. Eagan Press, St. Paul, MN.

29. Rioux, S., Pageau, D., Lajeunesse, J., Lafond, J., and Savard, M. E. 2005. Previous crop residues and Fusarium head blight on cereals. Pages 83-88 in: Proc. 4th Can. Workshop Fusarium Head Blight, Ottawa, Canada.

30. Schaafsma, A. W., Tamburic-Ilincic, L., and Hooker, D. C. 2005. Effect of previous crop, tillage, field size, adjacent crop, and sampling direction on airborne propagules of Gibberella zeae/Fusarium graminearum, Fusarium head blight severity, and deoxynivalenol accumulation in winter wheat Can. J. Plant Pathol. 27:217-224.

31. Schaafsma, A. W., Tamburic-Ilincic, L., Miller, J. D., and Hooker, D. C. 2001. Agronomic considerations for reducing deoxynivalenol in wheat grain. Can. J. Plant Pathol. 23:279-285.

32. Schmale D. G., III, Shah, D. A., and Bergstrom, G. C. 2005. Spatial patterns of viable spore deposition of Gibberella zeae in wheat fields. Phytopathology 95:472-479.

33. Shaner, G. 2003. Epidemiology of Fusarium head blight of small grain cereals in North America. Pages 84-119 in: Fusarium Head Blight of Wheat and Barley. K. J. Leonard and W. R. Bushnell, eds. American Phytopathological Society, St. Paul, MN.

34. Sutton, J. C. 1982. Epidemiology of wheat head blight and maize ear rot caused by Fusarium graminearum. Can. J. Plant Pathol. 4:195-209.

35. Teich, A. H., and Nelson, K. 1984. Survey of Fusarium head blight and possible effects of cultural practices in wheat fields in Lambton County in 1983. Can. Plant Dis. Surv. 64:11-13.

36. Tekauz, A., McCallum, B., and Gilbert, J. 2000. Review: Fusarium head blight of barley in western Canada. Can. J. Plant Pathol. 22:9-16.

37. Zadoks, J. C., Chang, T. T., and Konzak, C. F. 1974. A decimal code for the growth stages of cereals. Weed Res. 14:415-421. 